\title{
O debate sobre aborto na Câmara dos Deputados (1991-2014): posições e vozes das mulheres parlamentares*
}

Rayani Mariano** Flávia Biroli***

\section{Resumo}

Este artigo analisa os discursos sobre aborto proferidos pelas mulheres parlamentares na Câmara dos Deputados, entre 1991 e 2014. Tem como foco o estudo das posições dessas parlamentares nesse debate, com destaque para as mais ativas. A análise expõe quais argumentos as deputadas mobilizaram em defesa de suas posições e relaciona a atuação no debate sobre aborto a suas trajetórias, considerando o vínculo com religiões organizadas. $\mathrm{O}$ debate é situado no contexto das disputas entre movimentos feministas e grupos religiosos, no âmbito do Executivo e do Legislativo, o que permite perceber as reações a projetos de lei $e$ normas técnicas apresentados no período.

Palavras-chave: Aborto, Democracia, Câmara dos Deputados, Mulheres, Representação Política.

* Recebido em 10 de dezembro de 2015, aceito em 07 de março de 2017.

** Doutoranda em Ciência Política na Universidade de Brasília (UnB), BrasíliaDF, Brasil. rayanimar@hotmail.com

*** Professora associada do Instituto de Ciência Política da Universidade de Brasília (UnB) e pesquisadora do CNPq, Brasília-DF, Brasil. flaviabiroli@gmail.com 
The Debate about Abortion in the Chamber of Deputies (1991-2014): Positions and Voices of Women

\begin{abstract}
This article discusses pronouncements about abortion by women parliamentarians in Brazilian Chamber of Deputies between 1991 and 2014. The focus is on women 's positions, especially the ones that were most active in the debate about abortion, their arguments and its relations with religious ties. The analysis is also aware of the context in which that debate took place, assimilating information about disputes and the main actors (feminist movements, religious groups, and the State) and situating their reactions to projects and norms presented.
\end{abstract}

Keywords: Abortion, Democracy, Chamber of Deputies, Women, Political Representation. 


\section{Introdução}

Em outubro de 2015, o Brasil presenciou manifestações de rua massivas, em diferentes regiões do país, a favor do direito ao aborto. Milhares de mulheres protestaram contra o PL 5.069/2013, que foi aprovado na Comissão de Constituição e Justiça da Câmara dos Deputados no dia 21 de outubro de $2015 .{ }^{1} \mathrm{O}$ objetivo do PL é tornar mais difícil o acesso ao aborto nos casos de gravidez resultante de estupro. Juntamente com os casos em que a gravidez representa risco de vida para a mulher, a interrupção da gestação resultante de estupro está prevista no Código Penal brasileiro desde 1940. Em 2012, uma decisão do Supremo Tribunal Federal (STF) fez somar às duas exceções anteriores os casos de anencefalia fetal. Mais recentemente, em novembro de 2016, o STF firmou o entendimento de que a penalização do aborto até a $12^{\mathrm{a}}$ semana de gestação está em desacordo com a Constituição. Embora essa não seja uma decisão vinculante, é um novo passo, ao qual foram acrescidas duas ações que não foram ainda analisadas no momento em que esse texto foi finalizado: Ação Direta de Inconstitucionalidade (ADI 5581), que inclui a interrupção da gestação de mulheres infectadas pelo vírus Zika, e a Ação de Descumprimento de Preceito Fundamental (ADPF) apresentada pelo Partido Socialismo e Liberdade (PSOL) em março de 2017, que pede a descriminalização do aborto até a $12^{\mathrm{a}}$ semana de gestação.

Há, assim, variáveis novas no cenário político. Mas os padrões atuais das disputas vêm ganhando forma ao menos desde

\footnotetext{
1 A discussão aqui apresentada faz parte da pesquisa "Direito ao aborto $e$ sentidos da maternidade: atores e posições em disputa no Brasil contemporâneo", financiada pelo edital MCTI/CNPq/SPM-PR/MDA 32/2012. Agradecemos a Luis Felipe Miguel, que participou, juntamente com Flávia Biroli, da elaboração e coordenação da pesquisa, e às bolsistas do Grupo de Pesquisa sobre Democracia e Desigualdades (www.demode.unb.br) que trabalharam na coleta dos dados: Amanda Seabra, Carolina Souto, Débora Françolin, Isabella Rodrigues, Juliana Góes, Karine Farinha, Luciana Keller, Laura Sousa e Raquel Labarrere. A coleta ocorreu sob a supervisão de Rayani Mariano e Gabriela Dornelles.
} 
os anos 1990. A maior atuação política das igrejas evangélicas ${ }^{2}$, com o crescimento do número de parlamentares ligados a essas igrejas na Câmara dos Deputados que têm se aliado à Igreja Católica nessa pauta, contribui para a ampliação do número de proposições que representam retrocessos na legislação sobre direitos sexuais e reprodutivos. Nos anos 1990, pelo menos seis proposições foram apresentadas na Câmara dos Deputados com o objetivo de restringir a legalidade ou aumentar a punição para o aborto; entre 2000 e 2015, foram pelo menos 32 proposições. Entre estas estão propostas de emenda à Constituição que procuram incluir a inviolabilidade da vida desde a concepção (PECs 164/2012 e 29/2015), o PL 478/2007 (o chamado Estatuto do Nascituro, que confere ao embrião proteção jurídica) e o PL 6.335/2009 (que permite que agentes de saúde aleguem "objeção de consciência").

Nesse contexto, as mulheres permaneceram subrepresentadas. Se observarmos o período de reconstrução da democracia no Brasil após a ditadura de 1964, o número de mulheres eleitas não alcançou $10 \%$ do total de parlamentares eleitos em qualquer dos pleitos, mesmo com a instituição da Lei 9.504/97, que reserva para elas $30 \%$ das candidaturas nas eleições proporcionais.

Ao mesmo tempo, a posição relativa das mulheres na sociedade brasileira se modificou, com transformações significativas nos padrões de conjugalidade e na maternidade (as formas de organização das famílias são cada vez mais plurais, as mulheres hoje têm menos filhos, e mais tarde), ampliação do acesso à educação (elas têm em média maior tempo de estudo do

2 Vale observar que nas últimas décadas do século $\mathrm{XX}$, há uma relativa estagnação numérica das chamadas protestantes históricas (luteranas, batistas, presbiterianas, metodistas etc.) e um crescimento vertiginoso dos grupos pentecostais e neopentecostais, que hoje abarcam $60 \%$ dos evangélicos no Brasil. Essa mudança foi acompanhada pela flexibilização dos costumes, disseminação da teologia da prosperidade, investimento progressivo nos meios de comunicação e por uma maior capacidade de incorporar elementos da agenda política dos movimentos sociais (Machado, 2013). 
que eles) e uma presença maior e mais diversificada no mercado de trabalho (embora continuem a ser as principais responsáveis pelo trabalho doméstico e tenham uma remuneração média $26 \%$ menor que a deles, sua participação na força de trabalho remunerada mais do que triplicou desde os anos 1970).

Os movimentos feministas, atores nas disputas que se definem nesse processo, conquistaram algumas vitórias. ${ }^{3}$ Entre elas, estão as normas técnicas do Ministério da Saúde, publicadas em 1998 e 2005, que procuram garantir o acesso ao aborto nos casos previstos por lei. Está também a legislação específica para a violência contra as mulheres, com a Lei Maria da Penha (11.340, de 2006) e a lei do feminicídio (13.104, de 2015).

Em conjunto, as transformações de caráter sociológico $e$ as ações políticas para a ampliação dos direitos das mulheres têm provocado reações. Os padrões de atuação dos parlamentares religiosos nas décadas recentes não se explicam apenas desse prisma. Mas sua atuação específica na temática dos direitos reprodutivos, do aborto em especial, e da família pode ser lida como reação a essas mudanças, por meio da qual procuram angariar reconhecimento e votos de uma parcela da população que julgam ser afinada com uma agenda conservadora nos costumes e de retrocessos nos direitos.

A questão do aborto diz respeito diretamente à cidadania das mulheres, uma vez que a criminalização restringe sua autonomia para decidir sobre o que se passa no e com seu corpo (Biroli, 2014) e à sua integridade física e psíquica, comprometida pela criminalização e pela inacessibilidade do aborto nos casos em que é legal (Diniz et al., 2014), que configura a recusa desse direito como um problema de saúde pública.

A criminalização e os obstáculos para o acesso ao aborto não impedem que as mulheres o realizem. Estima-se que mais de uma em cada cinco mulheres brasileiras fez pelo menos um aborto

3 Para estudos que apresentam um panorama das formas de organização e das lutas dos movimentos feministas no Brasil, cf. Alvarez (1990), Machado (2014) e Pinto (2003). 
(Diniz e Medeiros, 2010:964). Nas circunstâncias em que são realizados no Brasil, eles levam a um grande número de mortes $e$ sequelas. Apesar de dados oficiais apontarem a diminuição da mortalidade materna por aborto, ele foi a causa de $8,4 \%$ das mortes maternas no ano de 2010, com variações regionais que expõem desigualdades significativas - no Amapá, é a causa de 33\% dessas mortes (Ministério da Saúde, 2012). São, ainda, 240 mil internações por ano no SUS para tratar complicações decorrentes de abortamentos (Ministério da Saúde, 2008).

O debate sobre aborto expõe também as rupturas com o princípio da laicidade do Estado $e$ os filtros sistemáticos $e$ diferenciados que se impõem para o acesso dos grupos sociais ao parlamento. É com base em crenças religiosas que o direito ao aborto é recusado, ainda que os argumentos que fundamentaram as posições contrárias no debate analisado nem sempre se expressem abertamente nesses termos. É com os recursos mobilizados pelas igrejas e seu acesso privilegiado a concessões de rádio e televisão que são construídas as carreiras políticas de seus integrantes.

Neste artigo, tendo em mente essa correlação de forças e o conjunto de variáveis exposto, analisamos o debate sobre aborto na Câmara dos Deputados com foco nos discursos sobre aborto feitos pelas parlamentares do sexo feminino. A pesquisa analisou todos os pronunciamentos sobre aborto feitos em plenário ao longo de 24 anos, durante seis legislaturas (da 49a, iniciada em janeiro de 1991, à 54, encerrada em janeiro de 2015). ${ }^{4}$ Os procedimentos metodológicos serão mais detalhados na segunda seção do artigo, mas antecipamos que a seleção foi feita por meio do site da Câmara dos Deputados e, posteriormente, foi

${ }^{4}$ Em sua dissertação de mestrado, Mariano (2015) apresenta o conjunto dos dados da pesquisa de maneira mais completa e analisa a variação de seus padrões, com destaque para as posições e os argumentos que as sustentaram. Miguel, Biroli e Mariano (2016) também apresentam um mapa mais geral desses dados, acompanhado da análise dos seus padrões. Outras discussões no âmbito da pesquisa podem ser encontradas no livro organizado por Biroli e Miguel (2016). 
preenchida uma ficha de análise para cada discurso, permitindo considerar a presença de posições e argumentos, assim como identificar quem foram os/as parlamentares que discursaram sobre o tema. Os pronunciamentos feitos pelas deputadas correspondem a $13,6 \%$ do total de 915 discursos que foram analisados e neste artigo mostramos suas características relativamente ao conjunto de pronunciamentos sobre aborto $e$, ainda, o perfil das mulheres parlamentares no que diz respeito a sua filiação ideológicopartidária e sua posição sobre o direito ao aborto.

O artigo está dividido em quatro seções, além desta introdução. A primeira faz uma breve exposição do contexto em que os debates se deram, destacando eventos e disputas que marcaram as interações na Câmara dos Deputados. Em seguida, apresentamos dados que permitem comparar a atuação de mulheres e homens na Câmara dos Deputados entre 1991-2014, no que diz respeito especificamente à questão do aborto. A terceira seção apresenta e discute os pronunciamentos sobre aborto feitos pelas mulheres parlamentares nesse mesmo período. Por fim, uma breve conclusão retoma a relação entre direitos das mulheres, aborto e representação política.

\section{Nota sobre o contexto das disputas, eventos $e$ atores}

O período da pesquisa se inicia em 1991, ano em que foram apresentados dois projetos de lei que tiveram como objetivo a ampliação do aborto legal, ambos propostos pelos/as parlamentares Eduardo Jorge (PT-SP) e Sandra Starling (PT/MG). O PL 20/1991 tratava da obrigatoriedade de atendimento pelo SUS nos casos de aborto previstos no Código Penal. O PL 1135/1991, por sua vez, objetivava suprimir o artigo 124 do Código Penal, que caracteriza como crime o aborto provocado pela gestante ou com seu consentimento. A tramitação dos dois projetos ajuda a entender as curvas no debate, que não foi homogêneo nos 24 anos analisados na pesquisa. 
Gráfico 1: Discursos sobre aborto pronunciados por mulheres e homens (1991-2014)

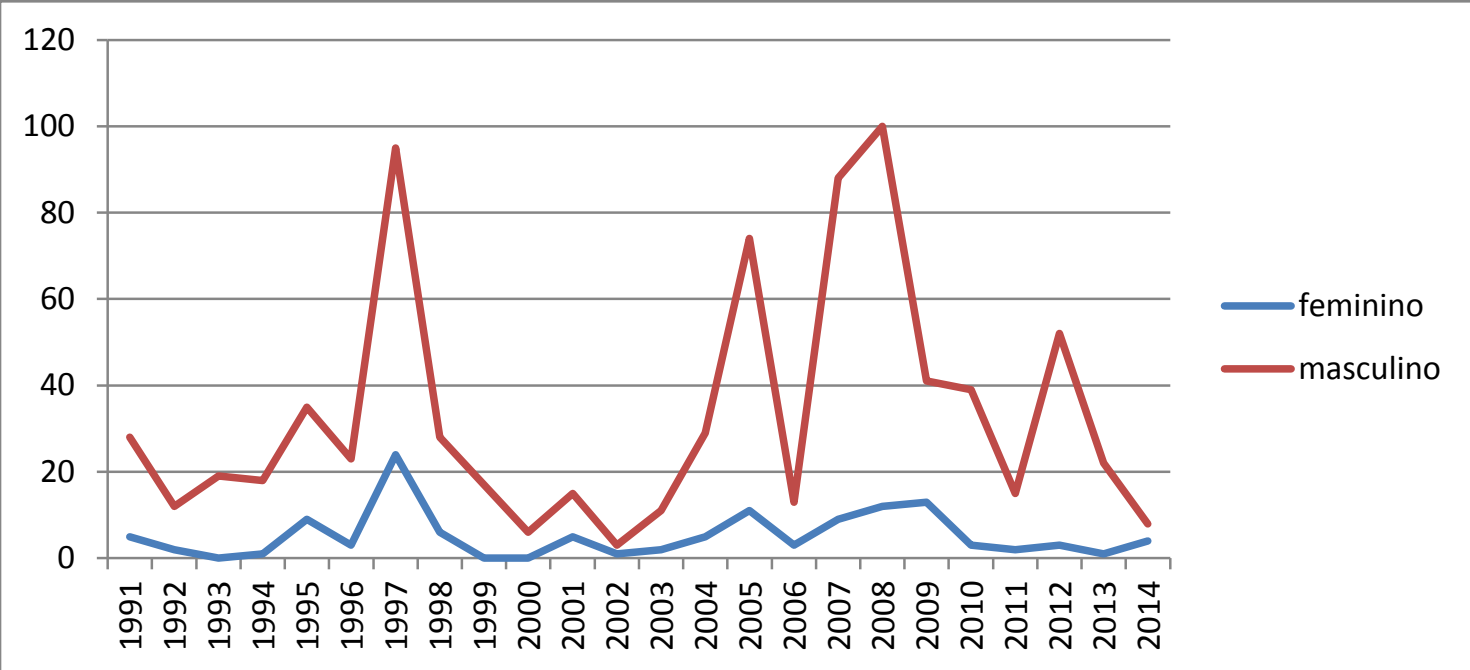

Fonte: Pesquisa "Direito ao aborto e sentidos da maternidade: atores e posições em disputa no Brasil contemporâneo".

No período de 1991 a 2014, quatro anos se destacam pelo grande número de pronunciamentos: 1997, 2005, 2007 e 2008. O ano de 1997 foi o campeão, com 119 discursos proferidos (13\%) e a ocorrência de dois eventos importantes. O primeiro foi a aprovação do PL 20/1991 na Comissão de Constituição e Justiça e de Cidadania, após ter sido aprovado, em 1995, na Comissão de Seguridade Social e Família. O segundo evento foi a visita do papa João Paulo II ao Brasil, que colaborou para ampliar a mobilização pela posição da Igreja Católica. Esse foi um dos fatores que influenciaram a tramitação, evitando o encaminhamento do projeto para votação no Senado, o que teria sido o trâmite regular nesse caso (Correa e Ávila, 2003).

Embora o projeto nunca tenha sido votado em plenário, seu objetivo foi atingido no ano seguinte por meio da Norma Técnica do Ministério da Saúde "Prevenção e Tratamento dos Agravos 
Resultantes de Violência Sexual Contra as Mulheres $e$ Adolescentes". A norma, publicada em $1998^{5}$, estabelece que mulheres que foram vítimas de violência sexual e queiram realizar um aborto sejam atendidas pelo SUS, com a apresentação de um Boletim de Ocorrência (BO). Mais tarde, a Lei 12.845/2013, que define violência sexual como "qualquer forma de atividade sexual não consentida", tornaria obrigatório o atendimento imediato no SUS, incluindo a realização de profilaxia da gravidez. Em 1997 e 1998, no entanto, muitos dos discursos analisados na pesquisa opunham-se ao PL 20/1991 e à norma técnica de 1998, justificando-se com o argumento de que "apenas o $\mathrm{BO}$ " não provaria que as mulheres haviam sido vítimas de estupro.

Depois desse período, o número de pronunciamentos sobre aborto cairia drasticamente na Câmara dos Deputados. Apenas em 2005 o debate se acirraria novamente, atingindo 85 pronunciamentos. O principal motivo foi a publicação da Norma Técnica de "Atenção Humanizada ao Abortamento". Nela, fica revogada a necessidade de apresentação de $\mathrm{BO}$ pelas mulheres que sofreram violência sexual para atendimento no SUS.

Em 2004, havia ocorrido a I Conferência Nacional de Políticas para as Mulheres e uma das demandas aprovadas foi a de revisão da legislação punitiva do aborto. A SPM apoiou a demanda e foi instituída uma comissão tripartite que discutiria, elaboraria e encaminharia uma proposta. A minuta elaborada pela comissão propunha o direito à interrupção da gravidez até a $12^{\mathrm{a}}$ semana, e até a $20^{\text {a }}$ nos casos de estupro, a obrigação do SUS e dos planos de saúde realizarem o atendimento e dava outras providências. Foi incorporada na forma de substitutivo ao PL 1.135/1991, mencionado anteriormente.

Em 2005, no entanto, não surgiria apenas uma movimentação correspondente à ampliação de direitos. Nesse ano, foi registrada a "Frente Parlamentar em Defesa da Vida -

${ }^{5}$ Embora o ano que consta na publicação impressa (e na sua versão digital) pelo Ministério da Saúde seja 1999, a norma é de novembro de 1998. Por isso há, ainda em 1998, discursos que a mencionam e procuram fazer frente a ela. 
Contra o Aborto", a primeira frente formada na Câmara que possuía a questão do aborto como a principal temática. Ela foi organizada principalmente pelo deputado espírita Luiz Bassuma (PT, PV/BA), que se tornou seu presidente e foi o parlamentar que mais pronunciou discursos sobre aborto no período pesquisado.

Pela análise dos discursos parlamentares, é possível notar que, desde a criação da frente, havia uma articulação com diferentes denominações religiosas e uma preocupação em pressionar os/as parlamentares para que eles/as se posicionassem publicamente sobre o assunto. Nas legislaturas que se seguiram também foram registradas frentes relacionadas à questão: "Frente Parlamentar Contra a Legalização do Aborto - Pelo Direito à Vida"; "Frente Parlamentar da Família e Apoio à Vida"; "Frente Parlamentar Mista em Defesa da Vida - Contra o Aborto".

O tema da família tem sido articulado com o do aborto e a organização das frentes parlamentares tem sido estratégica para fazer avançar temáticas que seriam destacadas na agenda política dos deputados, especialmente entre os evangélicos (Machado, 2013).

O DIAP produz uma Radiografia do Novo Congresso a cada eleição. O texto sobre as eleições de 2002 indicava que a bancada evangélica havia mantido seu tamanho, contando com aproximadamente 50 deputados (DIAP, 2002). Em 2006, o espaço reservado para a bancada evangélica aumentou no documento, devido à ampliação de sua atuação, mas o número de deputados evangélicos eleitos diminuiu, passando para 32 (DIAP, 2006). Em 2010, a bancada voltou a crescer, com a eleição de 70 deputados (DIAP, 2010).

Nota-se que a partir de 2005 uma maior organização político-religiosa por meio dessas frentes e de eventos públicos, como as marchas em defesa da vida, deu destaque à agenda conservadora que tematiza família e aborto. Em 2006, ano de eleições, o assunto não ganhou o mesmo destaque que ganharia nas eleições posteriores, mas nos anos seguintes é possível observar como essa articulação de parlamentares religiosos, que tem mais recentemente incluído outras bancadas conservadoras, 
conseguiu avançar na projeção das suas pautas no debate público dentro e fora do Congresso Nacional (Biroli; Miguel, 2016; Almeida; Bandeira, 2013; Mantovani, 2014; Miguel, 2012).

Em 2007 e 2008, quando se atingiria novamente a casa de 100 pronunciamentos (foram 97 em 2007 e 112 em 2008), os principais eventos já não eram normas para a garantia do acesso ao aborto legal. Em 2007, foi proposto o chamado Estatuto do Nascituro (478/2007), ainda em tramitação, que confere ao embrião proteção jurídica. Foi nesse mesmo ano, também, que ocorreu a $1^{\text {a }}$ Marcha Nacional em Defesa da Vida, depois organizada em diferentes locais do país. O ano de 2008 foi marcado pela derrota do PL 1.135/91 em votações na Comissão de Seguridade Social e Família e na Comissão de Constituição e Justiça. A norma técnica de 1998, assim como a lei de 2013 que dispõe sobre o atendimento a vítimas de violência sexual (Lei $12.845 / 2013)$, respondeu às demandas dos movimentos feministas e de certa forma preencheu o vazio deixado pela paralisação da tramitação do PL 20/1991. Ambas seriam colocadas em questão por iniciativas posteriores, como o PL 6.335/2009 e o PL $5.069 / 2013$, já mencionados, que procuram dificultar o acesso das mulheres ao aborto legal.

Pode ser feita uma leitura de que nesses 24 anos cobertos pela pesquisa houve um reforço das duas posições antagônicas. De um lado, ganharam reforço iniciativas de deputados de base religiosa com o objetivo de produzir recuos na legislação vigente. De outro, o feminismo e a agenda de defesa dos direitos das mulheres vêm ganhando novas adeptas e novas plataformas - a internet $e$, nela, as redes sociais, parecem ter um papel nessa dinâmica -, reforçando as manifestações pelo direito ao aborto, ainda que sua defesa seja minoritária e muito localizada dentro do Congresso, que permanece masculino e tem maior presença das igrejas. Os governos recentes jogaram um jogo arriscado da perspectiva dos direitos das mulheres: ao mesmo tempo que alguns avanços ocorreram $e$ houve maior permeabilidade aos movimentos feministas, as alianças estabelecidas (com destaque para as alianças entre os governos do PT e parlamentares de base 
evangélica) implicaram, em muitos momentos, evitar o enfrentamento e permitir recuos na implementação de políticas $e$ de campanhas educativas.

\section{Mulheres e homens no debate sobre aborto na Câmara dos Deputados}

Nas seis legislaturas entre 1991 e 2014 (49a a 54 $)$, foram proferidos em plenário, na Câmara dos Deputados, 915 discursos que trataram central ou lateralmente da questão do aborto. A coleta desses discursos foi feita em três momentos - agosto de 2013, agosto de 2014 e janeiro de 2015 - por meio do instrumento de busca disponível no site da Câmara dos Deputados (www.camara.leg.br), sempre com um mesmo conjunto de palavras-chave, definido por testes feitos previamente: "aborto", "abortamento", "interrupção voluntária da gravidez", "interrupção da gravidez", "interrupção voluntária da gestação" e "interrupção da gestação". 6

Para cada discurso, foi preenchida uma ficha, no software Sphinx Lexica, com informações e categorização dos discursos. As informações estavam centradas nas/os parlamentares (nome, partido, UF, sexo), na data do pronunciamento e na sua relação com eventos específicos. A categorização classificava a posição adotada pelas/os parlamentares nos discursos e os argumentos que a sustentavam, entre 7 categorias indicadas na ficha: ${ }^{7}$

1. a favor da ampliação do aborto legal: defende outras possibilidades de aborto, além dos casos previstos na legislação, e/ou argumenta por mais atendimento na rede hospitalar;

6 A busca retornou 939 discursos, dos quais 24 foram excluídos pela sua irrelevância para a pesquisa (são casos, por exemplo, em que a palavra aborto aparecia em sentido metafórico, sem relação com a temática da pesquisa).

7 Cada ficha passou por três fases: (1) preenchimento "cego" por duas pessoas; (2) conferência acompanhada por terceiros e discussão sobre eventuais discrepâncias, para ajuste da ficha; (3) revisão das fichas por pós-graduandas que acompanharam toda a pesquisa e supervisionaram o trabalho de preenchimento. 
2. a favor da manutenção da lei: defende a permanência da legislação. Trata-se, principalmente, de discursos que reagem a tentativas de mudança da lei;

3. a favor da restrição do aborto legal: defende a extinção de uma ou de todas as exceções na legislação que criminaliza o aborto;

4. contra o aborto (genérico): se posiciona contra o aborto, mas não menciona a legislação ou defende mudanças/retrocessos;

5. por novas medidas punitivas e/ou de controle: defende penas mais rigorosas para quem realiza aborto ou mais controle para impedir que seja realizado;

6. pela educação sexual e/ou planejamento familiar. defende mais ações direcionadas à educação sexual, principalmente nas escolas, e/ou mais programas para planejamento familiar, como aqueles focados na distribuição de contraceptivos;

7. não se posiciona: o discurso menciona a questão do aborto ou discute aspectos dessa questão, sem emitir posicionamento.

Para a análise dos dados, optamos em muitos momentos por agrupar as categorias 3, 4 e 5 em uma única - posições contrárias ao aborto -, como se verá.

$\mathrm{Na}$ ficha de classificação dos discursos, quando a posição é a favor da ampliação do aborto legal, há em seguida um item para indicação de qual ampliação estava sendo defendida, em que as opções são: (a) descriminalização total; (b) permissão em caso de inviabilidade do feto; (c) ampliação da assistência na rede hospitalar; (d) não indica que tipo de ampliação; (e) outra. Quando nessa classificação a posição é a favor da restrição do aborto legal, também há um item para indicação de qual restrição, com as seguintes opções: (a) proibição total; (b) estupro; (c) risco de vida da mãe; (d) inviabilidade do feto; (e) políticas de repressão ao aborto; (f) outra.

Nosso foco neste artigo é nos pronunciamentos feitos pelas parlamentares mulheres. Entre 1991 e 2014, elas pronunciaram 
13,6\% (124 discursos, contra 791 pronunciados por homens) do total de discursos analisados, numa atuação que, quantitativamente, ultrapassa em alguns pontos sua presença relativa na Câmara, que em nenhuma das legislaturas foi maior do que $9,9 \%$. De modo geral, as mulheres se pronunciaram mais nos anos em que a discussão foi mais intensa: 1997, 2005, 2008 e 2009.

Tabela 1: Número de pronunciamentos sobre aborto na Câmara dos Deputados, por sessão legislativa e por sexo (1991-2014)

\begin{tabular}{|c|c|c|c|}
\hline Sessão/Sexo & Mulheres & Homens & Total \\
\hline 1991 & 5 & 28 & 33 \\
\hline 1992 & 2 & 12 & 14 \\
\hline 1993 & 0 & 19 & 19 \\
\hline 1994 & 1 & 18 & 19 \\
\hline 1995 & 9 & 35 & 44 \\
\hline 1996 & 3 & 23 & 26 \\
\hline 1997 & 24 & 95 & 119 \\
\hline 1998 & 6 & 28 & 34 \\
\hline 1999 & 0 & 17 & 17 \\
\hline 2000 & 0 & 6 & 6 \\
\hline 2001 & 5 & 15 & 20 \\
\hline 2002 & 1 & 3 & 4 \\
\hline 2003 & 2 & 11 & 13 \\
\hline 2004 & 5 & 29 & 34 \\
\hline 2005 & 11 & 74 & 85 \\
\hline 2006 & 3 & 13 & 16 \\
\hline 2007 & 9 & 88 & 97 \\
\hline 2008 & 12 & 100 & 112 \\
\hline 2009 & 13 & 41 & 54 \\
\hline 2010 & 3 & 39 & 42 \\
\hline 2011 & 2 & 15 & 17 \\
\hline 2012 & 3 & 52 & 55 \\
\hline
\end{tabular}




\begin{tabular}{|c|c|c|c|}
\hline 2013 & 1 & 22 & 23 \\
\hline 2014 & 4 & 8 & 12 \\
\hline TOTAL & 124 & 791 & 915 \\
\hline
\end{tabular}

Fonte: Pesquisa "Direito ao aborto e sentidos da maternidade: atores $e$ posições em disputa no Brasil contemporâneo".

Por serem tão poucas as mulheres, pode ser enganoso comparar os percentuais de discursos pelo sexo. Mas os percentuais colaboram, apesar disso, para qualificar sua atuação: enquanto $13,6 \%$ do total de discursos foram pronunciados pelas mulheres, $40 \%$ do total de discursos favoráveis à ampliação do direito ao aborto foram de autoria delas. Esse dado indica que, embora a presença das mulheres seja pequena, sua participação nesse debate é relevante e é diferente da participação dos homens.

Tabela 2: Posições sobre aborto, por sexo

\begin{tabular}{|l|r|r|r|}
\hline $\begin{array}{l}\text { Posições } \\
\text { agrupadas/Sexo }\end{array}$ & Mulheres & \multicolumn{1}{|c|}{ Homens } & \multicolumn{1}{c|}{ Total } \\
\hline $\begin{array}{l}\text { a favor da ampliação } \\
\text { do aborto legal }\end{array}$ & $46,80 \%$ & $10,90 \%$ & $15,70 \%$ \\
\hline $\begin{array}{l}\text { a favor da manutenção } \\
\text { da lei }\end{array}$ & $12,10 \%$ & $14,40 \%$ & $14,10 \%$ \\
\hline $\begin{array}{l}\text { posições contrárias ao } \\
\text { aborto (agrupadas) }\end{array}$ & $23,40 \%$ & $67,90 \%$ & $61,90 \%$ \\
\hline $\begin{array}{l}\text { pela educação sexual } \\
\text { e/ou planejamento } \\
\text { familiar }\end{array}$ & $17,70 \%$ & $12,90 \%$ & $13,60 \%$ \\
\hline não se posiciona & $15,30 \%$ & $7,10 \%$ & $8,20 \%$ \\
\hline & $n=124$ & $n=791$ & $n=915$ \\
\hline
\end{tabular}

Fonte: Pesquisa "Direito ao aborto e sentidos da maternidade: atores e posições em disputa no Brasil contemporâneo".

Obs.: Os percentuais ultrapassam $100 \%$ porque era possível indicar até duas posições em cada discurso.

A posição mais frequente nos discursos proferidos pelas mulheres foi a defesa da ampliação do aborto legal, enquanto 
entre os deputados a maior concentração foi de posições contrárias ao aborto.

Quando observamos apenas os discursos favoráveis à ampliação proferidos pelas deputadas, 43,1\% defendiam a ampliação da rede hospitalar, $34,5 \%$ defendiam a descriminalização do aborto, $19 \%$ defendiam a interrupção em caso de inviabilidade do feto e 15,9\% defendiam a ampliação do aborto legal sem especificar de que forma. Entre os discursos favoráveis à ampliação feitos por homens, 45,3\% defendiam a descriminalização, $34,9 \%$ a ampliação da assistência na rede hospitalar, $18,6 \%$ a permissão em caso de inviabilidade do feto $e$ $12,8 \%$ não apresentavam especificações em sua defesa da ampliação do aborto legal.

Entre os discursos das deputadas que argumentavam pela restrição do direito ao aborto, $80 \%$ defendiam a proibição total $e$ $20 \%$ a restrição nos casos de estupro (o que preservaria como exceção o risco de vida das mulheres). Nos pronunciamentos dos deputados com essa posição, 64,5\% defendia a proibição total, $24,6 \%$ a restrição nos casos de estupro e em $8,7 \%$ dos discursos foi feita a defesa da restrição nos casos de inviabilidade do feto.

$\mathrm{O}$ total de deputadas que proferiram discursos sobre aborto no período pesquisado foi de 50. Entre elas, 28 pronunciaram apenas um discurso, 10 proferiram dois e 12 fizeram três discursos ou mais. No quadro abaixo, pode-se observar quem foram as deputadas que fizeram mais de três pronunciamentos sobre o tema $e$ as posições predominantes. 
Quadro 1: Deputadas que pronunciaram 3 ou mais discursos, número de pronunciamentos e posições predominantes (1991-2014)

\begin{tabular}{|c|c|c|c|c|}
\hline Parlamentar & $\begin{array}{c}\text { Número de } \\
\text { discursos }\end{array}$ & $\%$ & $\begin{array}{l}\text { Partido/ } \\
\text { UF }\end{array}$ & Posição predominante \\
\hline Marta Suplicy & 19 & $15,30 \%$ & PT/SP & A favor da ampliação do aborto legal \\
\hline Jandira Feghali & 11 & $8,90 \%$ & $\mathrm{PCdoB} / \mathrm{RJ}$ & A favor da ampliação do aborto legal \\
\hline Cida Diogo & 7 & $5,60 \%$ & PT/RJ & A favor da ampliação do aborto legal \\
\hline $\begin{array}{l}\text { Angela } \\
\text { Guadagnin }\end{array}$ & 6 & $4,80 \%$ & $\mathrm{PT} / \mathrm{SP}$ & Contra o aborto (genérico) \\
\hline Maria Elvira & 6 & $4,80 \%$ & $\mathrm{PMDB} / \mathrm{MG}$ & A favor da ampliação do aborto legal \\
\hline $\begin{array}{l}\text { Perpétua } \\
\text { Almeida }\end{array}$ & 6 & $4,80 \%$ & $\mathrm{PCdoB} / \mathrm{AC}$ & $\begin{array}{l}\text { A favor da manutenção da lei } \\
\text { A favor da ampliação do aborto legal }\end{array}$ \\
\hline Jô Moraes & 5 & $4,00 \%$ & $\mathrm{PCdoB} / \mathrm{MG}$ & $\begin{array}{r}\text { A favor da ampliação do aborto legal } \\
\text { Pela educação sexual }\end{array}$ \\
\hline Zelinda Novaes & 4 & $3,20 \%$ & $\begin{array}{l}\mathrm{PFL} / \mathrm{DEM} / \\
\mathrm{BA}\end{array}$ & $\begin{array}{r}\text { A favor da restrição do aborto legal } \\
\text { (proibição total) }\end{array}$ \\
\hline Fátima Bezerra & 3 & $2,40 \%$ & $\mathrm{PT} / \mathrm{RN}$ & Não se posiciona \\
\hline Fatima Pelaes & 3 & $2,40 \%$ & $\begin{array}{l}\text { PFL/DEM, } \\
\text { PSDB, } \\
\text { PMDB/AP }\end{array}$ & $\begin{array}{r}\text { A favor da ampliação do aborto } \\
\text { legal }^{8}\end{array}$ \\
\hline Simara Ellery & 3 & $2,4 \%$ & $\mathrm{PMDB} / \mathrm{BA}$ & $\begin{array}{r}\text { A favor da restrição do aborto legal } \\
\text { (estupro) }\end{array}$ \\
\hline $\begin{array}{l}\text { Telma de } \\
\text { Souza }\end{array}$ & 3 & $2,4 \%$ & $\mathrm{PT} / \mathrm{SP}$ & $\begin{array}{r}\text { A favor da manutenção da lei (contra } \\
\text { projeto que restringe o aborto em } \\
\text { casos de estupro) }\end{array}$ \\
\hline
\end{tabular}

Fonte: Pesquisa "Direito ao aborto e sentidos da maternidade: atores e posições em disputa no Brasil contemporâneo".

${ }^{8}$ Embora tenha sido predominante a posição favorável, em um de seus discursos a deputada apresentou posição contrária. As informações disponíveis permitem associar a mudança na sua posição a sua filiação à Assembleia de Deus. 
Como se pode observar, entre as 12 deputadas que mais se pronunciaram, apenas três - Angela Guadagnin (PT/SP), Zelinda Novaes (PFL-DEM/BA) e Simara Ellery (PMDB/BA) - sustentaram posições predominantemente contrárias ao direito ao aborto.

Das seis deputadas que fizeram mais de cinco discursos, a única que defendeu a descriminalização na maioria de seus pronunciamentos foi Cida Diogo (PT/RJ), que argumentou pela descriminalização em quatro dos seus sete pronunciamentos. Marta Suplicy (PT/SP), que proferiu 19 discursos, defendeu esse posicionamento em apenas três. Esses dados podem indicar ao menos duas possibilidades: as mulheres parlamentares se sentem coagidas ao defender suas posições, não se colocando abertamente a favor da descriminalização, ou elas fazem uma opção estratégica diante do contexto apresentado, optando por defender pequenos avanços ou evitar grandes retrocessos em vez de lutar abertamente pela descriminalização.

Entre os deputados homens favoráveis ao direito ao aborto, os mais ativos nos debates nesse período foram José Genoíno (PT/SP), Dr. Pinotti (PFL/DEM/SP) e Eduardo Jorge (PT/SP). José Genoíno pronunciou 25 discursos, tendo defendido abertamente a descriminalização do aborto em 18 deles. Os discursos do deputado Dr. Pinotti se concentraram na defesa do direito de interromper a gestação nos casos de inviabilidade do feto (posição defendida em quatro dos seis discursos), em um período em que essa exceção não havia sido ainda produzida pela decisão do STF de 2012. Dos seis pronunciamentos feitos por Eduardo Jorge, quatro foram a favor da ampliação da assistência na rede hospitalar, tema de um dos projetos de lei que apresentou em conjunto com a deputada Sandra Starling (PL 20/1991).

Destacam-se três partidos, Partido dos Trabalhadores (PT), Partido Comunista do Brasil (PCdoB) e Partido do Movimento Democrático Brasileiro (PMDB). Dos 124 pronunciamentos feitos pelas deputadas, 50 foram feitos por parlamentares do PT (15 deputadas), seguidos pelo PCdoB, com 27 pronunciamentos (seis deputadas), e pelo PMDB, com 16 pronunciamentos (sete 
deputadas). Entre os demais partidos, em conjunto, 22 deputadas se pronunciaram sobre aborto nos anos pesquisados. ${ }^{9}$

Tabela 3: Posições predominantes nos discursos, pelos partidos que concentraram os pronunciamentos das deputadas (1991-2014)

\begin{tabular}{|l|c|c|c|c|c|c|}
\hline Partido & $\begin{array}{c}\text { a favor da } \\
\text { ampliação } \\
\text { do aborto } \\
\text { legal }\end{array}$ & $\begin{array}{c}\text { a favor da } \\
\text { manutenção } \\
\text { da lei }\end{array}$ & $\begin{array}{c}\text { posições } \\
\text { contrárias } \\
\text { ao aborto }\end{array}$ & $\begin{array}{c}\text { pela } \\
\text { educação } \\
\text { sexual e/ou } \\
\text { planejamento } \\
\text { familiar }\end{array}$ & $\begin{array}{c}\text { não se } \\
\text { posiciona }\end{array}$ & $\begin{array}{c}\text { número de } \\
\text { discursos }\end{array}$ \\
\hline PT & $62 \%$ & $12 \%$ & $12 \%$ & $14 \%$ & $14 \%$ & 50 \\
\hline PCdoB & $66,7 \%$ & $11,1 \%$ & $0 \%$ & $22,2 \%$ & $18,5 \%$ & 27 \\
\hline PMDB & $18,8 \%$ & $18,8 \%$ & $43,8 \%$ & $12,5 \%$ & $12,5 \%$ & 16 \\
\hline
\end{tabular}

Fonte: Pesquisa "Direito ao aborto e sentidos da maternidade: atores e posições em disputa no Brasil contemporâneo".

Obs.: A soma das porcentagens é superior a $100 \%$ porque em cada ficha era possível marcar até duas posições.

Quando observamos a ideologia dos partidos, vemos que $71 \%$ das deputadas eram de partidos de esquerda, $14,5 \%$ de centro, e $13,7 \%$ de direita. ${ }^{10}$ Não é possível afirmar que deputadas de partidos de esquerda são favoráveis ao aborto, enquanto as de direita se opõem a esse direito, mas é possivel identificar algumas diferenças significativas. Entre os discursos favoráveis à ampliação do aborto legal pronunciados pelas deputadas, $89,7 \%$ foram proferidos por mulheres de partidos de esquerda; entre os discursos contrários, $44,8 \%$ foram feitos por deputadas de partidos

9 Fátima Pelaes foi aqui computada entre as 22 deputadas pertencentes aos demais partidos (passou pelo DEM e pelo PSDB), embora tenha se filiado posteriormente ao PMDB e pronunciado um de seus discursos nessa condição.

${ }^{10}$ Os seguintes partidos foram classificados como de esquerda: PCdoB, PDT, PHS, PPS, PROS, PSB, PSOL, PT e PV. Como centro, foram classificados $\mathrm{PMDB}$ e PSDB. Os demais partidos foram classificados como direita. Em um dos discursos $(0,8 \%)$, a parlamentar estava sem partido no momento do pronunciamento. Foi o caso da deputada Luciana Genro, que havia saído do PT e ainda não estava no PSOL. 
de direita. Quando observamos apenas os discursos dos parlamentares homens, $64 \%$ dos discursos favoráveis à ampliação foram pronunciados por parlamentares de partidos de esquerda, $49 \%$ dos discursos que se opunham a esse direito foram feitos por parlamentares de partidos de direita. Entre os partidos de esquerda, os discursos favoráveis ao direito ao aborto foram proferidos por 42 parlamentares, entre os quais 18 mulheres; os discursos contrários foram mais concentrados em alguns parlamentares - 33 parlamentares, entre os quais três mulheres.

$\mathrm{O}$ debate sobre aborto está intimamente ligado à religião. Ainda que nem sempre de maneira explícita, crenças religiosas são a base para a noção de "inviolabilidade da vida". A ideia de escolha da mulher, de autonomia sobre seu corpo, é antagônica à ideia de que a vida é uma criação divina na qual as mulheres não poderiam deliberadamente interferir. No Brasil, a Igreja Católica e, mais recentemente, as evangélicas são os atores que agem mais sistematicamente contra o direito ao aborto, com participação ativa nos debates dentro e fora do Congresso e ações estratégicas para influenciar a legislação.

A maioria dos/as deputados/as que priorizam a questão do aborto em seus discursos, com posição contrária a esse direito, pertence a alguma religião. Entre as/os 39 parlamentares que pronunciaram cinco ou mais discursos no período da pesquisa, 14 são evangélicos (todos homens), 13 são católicos (12 homens $e$ uma mulher) e um (homem) é espírita. Entre os 14 deputados evangélicos que mais se pronunciaram, nove são da Igreja Assembleia de Deus. ${ }^{11}$

Os pentecostais são o grupo evangélico com maior representação na Câmara e têm atuado para impedir as iniciativas do governo federal de avanços no campo dos direitos humanos,

\footnotetext{
${ }^{11}$ Desses/as 39 parlamentares, 16 se autoidentificaram como pertencentes a alguma religião em seus sites oficiais na internet ou nos próprios discursos. Para complementar essa informação, foi realizada uma pesquisa na internet em sites de notícias e no Facebook, na qual foi encontrada a religião de mais 13 parlamentares. Não foi possível identificar a religião de 10 deputados, sendo que somente um entre os não identificados se pronunciou contra o aborto.
} 
com foco em mulheres e homossexuais. Com base em estudos que permitem acompanhar a atuação desse grupo, Machado (2013) ressalta que, a despeito do pensamento dominante ser tradicionalista, a posição das igrejas evangélicas sobre aborto não é homogênea. Lideranças importantes da Igreja Universal do Reino de Deus (IURD), como Edir Macedo e o senador Marcelo Crivella, possuem posições mais liberais. Também têm peso alianças entre as igrejas pentecostais e a Igreja Católica, que vêm se associando nessas pautas, ainda que seja possível, ao menos a título de hipótese para investigação, observar uma certa divisão do trabalho no Congresso, com líderes católicos e evangélicos dando maior prioridade a determinados temas, projetos e comissões.

Entre os deputados homens mais ativos no debate sobre aborto na Câmara, fica claro que a prioridade do tema está relacionada a suas crenças religiosas. Os parlamentares Luiz Bassuma (PT, PV/BA), Severino Cavalcanti (PP, PFL/DEM/PE) e Costa Ferreira (PFL/DEM, PP, PSC/MA) pronunciaram 65, 40 e 39 discursos, respectivamente. O primeiro é espírita, o segundo católico e o terceiro evangélico e os três se autoidentificaram como religiosos em seus discursos.

Entre as parlamentares que se pronunciaram, foi possível identificar 16 (32\% das 50) como religiosas. Entre elas, oito são católicas, sete são evangélicas, e uma se definiu apenas como cristã. Entre as deputadas evangélicas, duas são da Assembleia de Deus, uma da Igreja Universal do Reino de Deus, uma da Igreja Batista, uma da Igreja Presbiteriana, uma da Igreja Cristã Evangélica e uma sem igreja identificada. ${ }^{12}$

Como esperado, a maior parte das deputadas que possuem alguma religião defendeu posições contrárias ao aborto. Entre 15 mulheres que discursaram contra esse direito, dez se autoidentificaram ou foram identificadas como filiadas a alguma denominação religiosa. Entre as deputadas mulheres que mais se

\footnotetext{
${ }^{12}$ Apenas cinco deputadas se autoidentificaram como religiosas nos próprios discursos. Nos demais casos, foi feita busca, como identificado anteriormente, para complementação das informações.
} 
pronunciaram, apenas a parlamentar Angela Guadgnin (PT/SP), que pronunciou seis discursos sempre sustentando posição contra o direito ao aborto, se autoidentificou como católica nos próprios discursos, mencionando sua participação na Comissão Diocesana em Defesa da Vida.

Entre as mulheres que defenderam a ampliação do aborto legal, três apresentam filiação religiosa. Trata-se das deputadas Iara Bernardi (PT/SP), que defendeu em seu discurso a ampliação da assistência na rede hospitalar, Vanessa Grazziotin (PCdoB/AM), que se posicionou a favor do direito de interromper a gestação nos casos de inviabilidade do feto, e Fátima Pelaes (PSDB, PFL/DEM, $\mathrm{PMDB} / \mathrm{AP}$ ), que defendeu a descriminalização em um dos seus discursos, mas posteriormente assumiu uma posição contrária ao direito ao aborto.

Além da autoidentificação pela religião, as mulheres também se autoidentificaram nos discursos como mães $e$ mulheres. Em 11 pronunciamentos, as parlamentares se autoidentificaram como mães, sendo que cinco $(45,5 \%)$ deles foram contrários ao aborto e três $(27,3 \%)$ foram favoráveis à ampliação do aborto legal. Além disso, em dez desses discursos em que as deputadas se definiram como mães, elas também se caracterizaram como mulheres. Nos exemplos a seguir é possível observar a mobilização da maternidade em pronunciamentos com posições antagônicas:

[contra o direito ao aborto] Sou mulher, médica, pediatra, mãe, avó. Trabalho há mais de 25 anos com comunidades, mais exatamente com planejamento familiar, com informações sobre métodos anticoncepcionais, sobre o momento da fecundação e do ciclo menstrual. Desse modo, não estou falando com base no que ouvi, mas pela experiência de vida.

Sei muito bem que o direito da mulher termina onde começa o da criança. A mulher não pode alegar o direito de matar o nenê, que não tem condições de se defender. A mãe pode se defender, mas a criança, não (Deputada Angela Guadagnin - PT/SP, 08/12/2005). 
[a favor da ampliação do aborto legal] Tenho 2 filhos e sei da dimensão superior da maternidade, Sr. Presidente. A maternidade transforma a mulher em força maior de continuidade da espécie e de transformação da natureza. Mas temos de ter a compreensão de que, se no cotidiano da vida deste país, no seio das populações mais pobres, há um conjunto de pessoas em risco de vida, ou em risco de saúde, cabe ao Estado brasileiro, cabe aos governos darlhes cobertura, com a adoção de políticas públicas. (Deputada Jô Moraes - PCdoB/MG, 09/05/2008).

Vale observar também a participação das deputadas nas frentes relacionadas à questão do aborto. Das 50 mulheres que se pronunciaram sobre o tema, nove fizeram parte de uma das frentes organizadas contra o direito ao aborto nesse período (Frente Parlamentar em Defesa da Vida - Contra o Aborto; Frente Parlamentar da Família e Apoio à Vida; Frente Parlamentar Mista em Defesa da Vida - Contra o Aborto).

A participação na proposição de projetos de lei também traz informações sobre como se deu a atuação dessas parlamentares. Entre 1991 e 2014, foram propostos 63 projetos focados na questão do aborto - na legislação, nas condições de acesso ao aborto legal, na punição ao aborto, na ampliação das informações sobre gravidez e sobre aborto clandestino com o objetivo de punir abortos ilegais. Desse total, dez tiveram como autoras mulheres (sete em co-autoria com homens). Entre esses dez, a grande maioria - oito projetos - propõe a ampliação do aborto legal no Brasil. ${ }^{13}$ Entre as 53 proposições (PLs, PECs e PLP) apresentadas apenas por homens, diferentemente, a maioria implicava restrições ou medidas punitivas (36 proposições) e apenas 17 objetivam a ampliação do aborto legal.

\footnotetext{
${ }^{13}$ Essa posição se refere ao momento da proposição (um exemplo é o das propostas que tinham como objetivo a ampliação do aborto legal para os casos de má-formação fetal antes da decisão do STF, de 2012).
} 
Quadro 2: Projetos de Lei sobre aborto propostos pelas deputadas (1991-2014)

\begin{tabular}{|l|l|l|}
\hline Parlamentar & Projeto de Lei & \multicolumn{1}{|c|}{ Ementa } \\
\hline $\begin{array}{l}\text { Sandra Starling } \\
\text { (PT/MG); Eduardo } \\
\text { Jorge (PT/SP) }\end{array}$ & PL 20/1991 & $\begin{array}{l}\text { Dispõe sobre a obrigatoriedade de atendimento dos } \\
\text { casos de aborto previstos no Código Penal, pelo } \\
\text { SUS. }\end{array}$ \\
\hline $\begin{array}{l}\text { Sandra Starling } \\
\text { (PT/MG); Eduardo } \\
\text { Jorge (PT/SP) }\end{array}$ & PL 1104/91 & $\begin{array}{l}\text { Propõe que não seja considerada falta ao serviço a } \\
\text { ausência da empregada durante licenciamento } \\
\text { compulsório por motivo de aborto. }\end{array}$ \\
\hline $\begin{array}{l}\text { Sandra Starling } \\
\text { (PT/MG); Eduardo } \\
\text { Jorge (PT/SP) }\end{array}$ & PL 1135/91 & $\begin{array}{l}\text { Suprime o artigo que caracteriza crime o aborto } \\
\text { provocado pela gestante ou com seu } \\
\text { consentimento. }\end{array}$ \\
\hline $\begin{array}{l}\text { Sandra Starling } \\
\text { (PT/MG); Eduardo } \\
\text { Jorge (PT/SP) }\end{array}$ & PL 1174/91 & $\begin{array}{l}\text { Dispõe sobre autorização do aborto quando a } \\
\text { gravidez representar riscos de vida e saúde física ou } \\
\text { psíquica da gestante. }\end{array}$ \\
\hline Marta Suplicy (PT/SP) & PL 1956/96 & $\begin{array}{l}\text { Autoriza a interrupção de gravidez quando o } \\
\text { produto da concepção não apresenta condições de } \\
\text { sobrevida em decorrência de malformação } \\
\text { incompatível com a vida ou de doença } \\
\text { degenerativa incurável. }\end{array}$ \\
\hline $\begin{array}{l}\text { Jandira Feghali } \\
\text { (PCdoB/RJ); Alice } \\
\text { Portugal (PCdoB/BA); } \\
\text { lara Bernardi (PT/SP) }\end{array}$ & PL 4403/2004 & $\begin{array}{l}\text { Isenta de pena a prática de aborto terapêutico" em } \\
\text { caso de anomalia do feto. }\end{array}$ \\
\hline $\begin{array}{l}\text { Luciana Genro (sem } \\
\text { partido); Dr. Pinotti } \\
\text { (PFL/DEM/SP) }\end{array}$ & PL 4834/2005 & $\begin{array}{l}\text { Isenta de punição o aborto provocado por médico } \\
\text { quando o feto é portador de anencefalia. }\end{array}$ \\
\hline $\begin{array}{l}\text { Angela Guadagnin } \\
\text { (PT/SP); Luiz } \\
\text { Bassuma (PT/BA) }\end{array}$ & PL 5364/2005 & $\begin{array}{l}\text { Dispõe sobre a punibilidade do aborto no caso de } \\
\text { gravidez resultante de estupro. }\end{array}$ \\
\hline $\begin{array}{l}\text { Cida Diogo (PT/RJ) } \\
\text { Jusmari Oliveira } \\
\text { (PR/BA); Henrique } \\
\text { Afonso (PT/AC) }\end{array}$ & PL 660/2007 $1763 / 2007$ & $\begin{array}{l}\text { Isenta de pena a prática de "aborto terapêutico" em } \\
\text { caso de grave e incurável anomalia do feto. }\end{array}$ \\
\hline $\begin{array}{l}\text { Dispõe sobre a assistência à mãe e ao filho gerado } \\
\text { em decorrência de estupro. Na justificativa, afirma } \\
\text { que "punir a criança com a morte por causa do } \\
\text { estupro efetuado pelo seu pai é uma injustiça } \\
\text { monstruosa". }\end{array}$ \\
\hline
\end{tabular}

Fonte: Pesquisa "Direito ao aborto e sentidos da maternidade: atores e posições em disputa no Brasil contemporâneo". 
Vale observar que o padrão de atuação varia bastante

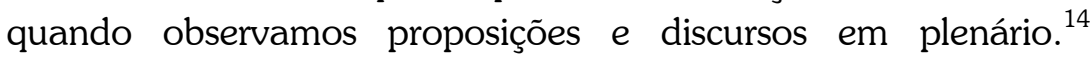
Apesar de ter sido a parlamentar que mais propôs projetos, com quatro PLs, a deputada Sandra Starling (PT/MG) proferiu apenas um discurso, em 1997. Na ocasião, a parlamentar defendeu o PL 20/91 e afirmou:

V. Exas. nunca pediram a revogação do art. 128 do Código Penal, porque a hipocrisia permanece na nossa sociedade. As mulheres ricas fazem, fizeram e farão não apenas aborto nessas duas condições, mas em qualquer circunstância. Os parlamentares, a Igreja e a polícia sabem que as mulheres ricas fazem o aborto. V. Exas. agora estão indignados porque estamos defendendo os excluídos, as mulheres pobres da nossa população (Deputada Sandra Starling (PT/MG), 26/11/1997).

Além dela, duas outras deputadas que propuseram projetos não estiveram entre aquelas que mais se pronunciaram (Luciana Genro e Jusmari Oliveira, cada uma com dois discursos).

\section{$\mathrm{O}$ que dizem as deputadas}

Além das posições sobre o direito ao aborto, a base de dados da pesquisa possibilita que sejam observados os argumentos que as/os parlamentares mobilizaram para defender suas posições. Foi realizado um trabalho de padronização que permitiu a tipificação de 14 argumentos com base na frequência. A análise qualitativa, por sua vez, foi feita com base na leitura dos discursos e destaque dos enunciados representativos das posições,

\footnotetext{
${ }^{14}$ Nesta pesquisa, não foi feito o acompanhamento mais detalhado da participação nas comissões, algo que é parte da agenda das nossas pesquisas em curso. Esse acompanhamento trará, sem dúvida, informações relevantes sobre a atuação das deputadas, que não estão contidas na base de dados sobre discursos e no mapeamento dos projetos propostos.
} 
o que permite compreender a centralidade de determinadas elaborações, assim como sua transversalidade no debate.

Nos discursos favoráveis à ampliação do aborto legal ou que defendiam a manutenção da lei com o objetivo de contrariar projetos que propunham a restrição do direito ao aborto, os argumentos mais comuns foram aqueles de saúde pública, liberdade individual, injustiça social, laicidade do Estado $e$ questões jurídicas. Já nos pronunciamentos contrários, os argumentos mais frequentes foram o da inviolabilidade da vida, razões religiosas, morais, de remissão à opinião pública $e$ novamente as questões jurídicas.

Alguns argumentos foram utilizados tanto nos discursos contrários quanto nos favoráveis. Isso se deu em especial com os argumentos da saúde pública e no jurídico.

Tabela 4: Argumento principal nos pronunciamentos sobre aborto, segundo sexo do/a parlamentar (1991-2014)

\begin{tabular}{|l|r|r|r|r|r|r|}
\hline & \multicolumn{2}{|c|}{ Mulheres } & \multicolumn{2}{c|}{ Homens } & \multicolumn{2}{c|}{ TOTAL } \\
\hline $\begin{array}{c}\text { Argumento } \\
\text { principal/Sexo }\end{array}$ & $\begin{array}{c}\mathrm{N}^{\circ} \\
\text { discursos }\end{array}$ & Freq. & $\begin{array}{c}\mathrm{N}^{\circ} \\
\text { discursos }\end{array}$ & Freq. & $\begin{array}{c}\mathrm{N}^{\circ} \\
\text { discursos }\end{array}$ & Freq. \\
\hline inviolabilidade da vida & 14 & $11,30 \%$ & 268 & $33,90 \%$ & 282 & $30,80 \%$ \\
\hline religiosos (explícitos) & 5 & $4,00 \%$ & 100 & $12,60 \%$ & 105 & $11,50 \%$ \\
\hline saúde pública & 31 & $25,00 \%$ & 63 & $8,00 \%$ & 94 & $10,30 \%$ \\
\hline Jurídicos & 9 & $7,30 \%$ & 46 & $5,80 \%$ & 55 & $6,00 \%$ \\
\hline $\begin{array}{l}\text { morais (não } \\
\text { explicitamente } \\
\text { religiosos) }\end{array}$ & 5 & $4,00 \%$ & 38 & $4,80 \%$ & 43 & $4,70 \%$ \\
\hline opinião pública & 7 & $5,60 \%$ & 36 & $4,60 \%$ & 43 & $4,70 \%$ \\
\hline liberdade individual & 11 & $8,90 \%$ & 24 & $3,00 \%$ & 35 & $3,80 \%$ \\
\hline estratégia imperialista & 0 & $0,00 \%$ & 19 & $2,40 \%$ & 19 & $2,10 \%$ \\
\hline Científicos & 1 & $0,80 \%$ & 16 & $2,00 \%$ & 17 & $1,90 \%$ \\
\hline
\end{tabular}




\begin{tabular}{|l|r|r|r|r|r|r|}
\hline $\begin{array}{l}\text { usurpação de poderes } \\
\text { do Legislativo }\end{array}$ & 0 & $0,00 \%$ & 16 & $2,00 \%$ & 16 & $1,70 \%$ \\
\hline injustiça social & 7 & $5,60 \%$ & 5 & $0,60 \%$ & 12 & $1,30 \%$ \\
\hline laicidade do Estado & 1 & $0,80 \%$ & 6 & $0,80 \%$ & 7 & $0,80 \%$ \\
\hline $\begin{array}{l}\text { controle sobre o } \\
\text { próprio corpo }\end{array}$ & 3 & $2,40 \%$ & 1 & $0,10 \%$ & 4 & $0,40 \%$ \\
\hline macroeconómicos & 0 & $0,00 \%$ & 3 & $0,40 \%$ & 3 & $0,30 \%$ \\
\hline Outros & 1 & $0,80 \%$ & 15 & $1,90 \%$ & 16 & $1,70 \%$ \\
\hline $\begin{array}{l}\text { sem nenhum } \\
\text { argumento }\end{array}$ & 29 & $23,40 \%$ & 135 & $17,10 \%$ & 164 & $17,90 \%$ \\
\hline TOTAL & 124 & $100 \%$ & 791 & $100 \%$ & 915 & $100 \%$ \\
\hline
\end{tabular}

Fonte: Pesquisa "Direito ao aborto e sentidos da maternidade: atores e posições em disputa no Brasil contemporâneo".

Obs: A pesquisa permitia identificar mais de um argumento por discurso, mas havia também um campo para a identificação do argumento principal (aquele que predominava sobre os demais).

Entre os 58 discursos favoráveis ao direito ao aborto, 25 $(43,1 \%)$ defenderam a ampliação da assistência na rede hospitalar, 20 (34,5\%) defenderam a descriminalização, 11 (19\%) defenderam a permissão em caso de inviabilidade do feto e nove $(15,5 \%)$ defenderam o aborto sem indicar que tipo de ampliação deveria ser efetuado.

O argumento da "saúde pública" foi o principal argumento em $24(41,4 \%)$ dos discursos nos quais é sustentada posição em defesa da ampliação do aborto legal. Observa-se, assim, uma relação entre os pronunciamentos das parlamentares $e \quad o$ enquadramento adotado pelos movimentos feministas. A escolha tem sido feita, de maneira estratégica, para chamar a atenção para o fato de que não está em questão apenas o embrião (ou feto), mas também a vida das mulheres. A recusa do direito ao aborto, segundo tem sido argumentado, não impede a interrupção da gestação, mas obriga as mulheres a recorrer a abortos clandestinos, colocando sua vida e saúde em risco. 
É essa argumentação que está presente no discurso da deputada Socorro Gomes (PCdoB/PA, 1991), ao dizer que "quando defendemos a legalização do aborto, estamos, sim, Senhores, defendendo a vida de milhares de mulheres que morrem anualmente em nosso País por não terem direito nem acesso a uma assistência médica". O mesmo pode ser observado no pronunciamento da deputada Cida Diogo (PT/RJ):

(...) é justo o que ocorre em nosso País com a mulher que toma a decisão de fazer o aborto, muitas vezes uma decisão isolada, por estar sozinha, em um momento em que se sente abandonada, em um momento de muita dor, de muita dificuldade? Muitas vezes essa mulher usa métodos extremamente agressivos à sua vida, à sua saúde, e por isso muitas morrem, porque introduzem agulhas de tricô para provocar aborto, utilizam métodos os mais absurdos, que perfuram o útero, ou que provocam infecção grave, ou hemorragia grave, que evolui para a morte. E muitas vezes essa mulher tem 2 ou 3 filhos, que perdem a referência materna (Deputada Cida Diogo, 08/05/2008).

O segundo argumento principal mais frequente nos discursos das parlamentares favoráveis ao aborto é o da liberdade individual (vale lembrar que entre os homens ele ficou na sétima posição). Isso não significa que ele tenha tido, como argumento, centralidade na construção da defesa da descriminalização pelas parlamentares. Entre os 20 discursos proferidos por mulheres que defendiam a descriminalização, o argumento da liberdade individual só foi o principal em dois, indicando que quando as parlamentares defenderam o acesso irrestrito ao aborto, elas optaram sobretudo por colocar o problema em termos de saúde pública.

Mas há uma especificidade que merece destaque. Nos discursos em que se recorreu ao argumento da liberdade individual, houve maior ênfase na agência das mulheres, deslocando o enquadramento para o direito a decidir sobre suas vidas. É o caso do pronunciamento da deputada Perpétua 
Almeida (PCdoB/AC) contra a CPI do Aborto e em defesa da descriminalização, em que ressalta a defesa do "direito de liberdade e de livre decisão das mulheres brasileiras" (Deputada Perpétua Almeida, 12/12/2008).

Esse argumento esteve também associado à crítica que as deputadas fizeram em meados dos anos 1990 às barreiras impostas para a aprovação do PL 20/1991. Foi mobilizado, ainda, na crítica à PEC 25/1995, proposta por Severino Cavalcanti (PPB/PE), que procura estabelecer a inviolabilidade do direito à vida desde a concepção. O discurso da deputada Maria Elvira (PMDB/MG) exemplifica essa posição em pronunciamento que procurava garantir as exceções previstas por lei, colocadas em risco pela PEC, mobilizando o argumento da liberdade individual com destaque para a agência das mulheres:

(...) nós, Deputadas desta Casa, estamos absolutamente pasmas diante do que está acontecendo. De repente, a atual situação faz recordar aquelas histórias que nunca se pôde imaginar, a de que a mulher fosse a última a participar de um processo de decisão da sua vida. Refirome ao caso do estupro, suprema das supremas violências que se comete contra o sexo feminino (Deputada Maria Elvira, 14/12/1995).

A conexão entre liberdade individual, direitos individuais e laicidade também foi percebida em vários discursos. O exercício da liberdade foi, nesses casos, colocado como parte do direito fundamental das mulheres como indivíduos a decidir sobre sua vida, algo que seria restrito quando se rompe com a laicidade:

É um absurdo manter argumentos religiosos para obrigar a mulher a levar a termo a gravidez quando sabe que não poderá conviver com seu filho. Quem quiser levar a gravidez adiante que a leve, é um direito; a lei não obriga o contrário. Mas a mulher precisa ter o direito de interrompêla nesses casos, para preservar sua saúde física e mental $e$ sua vida (Deputada Jandira Feghali - PCdoB/RJ, 18/11/2004). 
O argumento do direito ao "controle sobre o próprio corpo" esteve, no entanto, presente em apenas um dos discursos que defendiam a descriminalização ( $e$ em dois que defendiam a manutenção da lei), o que expõe limites da argumentação - nesse caso, pode-se falar em uma desconexão com o debate nos movimentos feministas, embora também entre esses a opção estratégica tenha sido acentuar a questão da saúde pública e não a da autonomia das mulheres. A afirmação da deputada Marta Suplicy (PT/SP, 26/11/1997) de que o debate "não é de fato sobre a constitucionalidade ou o direito à vida, mas sobre o último baluarte do poder do homem sobre a mulher - seu direito de decidir sobre seu corpo" foi, assim, exceção no debate.

Entre os discursos contrários ao direito ao aborto proferidos pelas deputadas, $\mathrm{o}$ argumento mais frequente foi $\mathrm{o}$ da "inviolabilidade da vida". É ele que de fato polariza, no período, com o argumento da saúde pública (e, com menos centralidade, com o da liberdade individual e o do direito ao corpo).

Os oito discursos pronunciados pelas mulheres em defesa da proibição total do aborto traziam o argumento da inviolabilidade da vida. A maioria deles (cinco discursos) foi pronunciada em 2005 para expressar a oposição das parlamentares à criação da comissão tripartite. Um trecho do discurso da deputada Elaine Costa (PTB/RJ) exemplifica esse movimento:

A luta pela vida já começou. Convoco todos os setores sociais que acreditam na dignidade da pessoa humana, no valor dos direitos humanos desde a concepção, a se unirem para denunciar em alto e bom som os enganos, as mentiras e a prepotência de movimentos sociais fanáticos por suas falsas ideologias e que fingem agir em defesa das mulheres, mas agem de fato em defesa apenas de si mesmos (Deputada Elaine Costa, 02/12/2005).

Em um dos discursos, a deputada Solange Almeida (PMDB/RJ), que foi a relatora do Estatuto do Nascituro na Comissão de Seguridade Social e Família e apresentou um 
parecer pela sua aprovação, disse que era contra a prática do aborto por razões religiosas, mas também

por razões morais e éticas, na medida em que, de acordo com os mais altos valores da humanidade, considero inadmissível o homicídio, independentemente da idade ou da condição física da vítima (Deputada Solange Almeida, 20/02/2008).

Essa fusão entre religião e ética e a confusão estratégica entre aborto e homicídio expõem conexões entre os argumentos mobilizados para sustentar as posições contrárias ao direito ao aborto dentro do parlamento e o enquadramento dos movimentos "pró-vida" nesse contexto. Como definiu a deputada Zelinda Novaes (PFL/DEM/BA), "o aborto é homicídio, é assassinato. E não há argumentos, por mais dolorosos que sejam, que justifiquem a morte de um inocente" (09/12/2015).

Nos discursos contrários ao aborto, a "defesa da vida" ganha sentido nos argumentos mais presentes nesses discursos religiosos (15 discursos), morais (11 discursos), jurídicos (10 discursos) e científicos (sete discursos). Há um deslizamento entre argumentos religiosos e morais ou entre esses e argumentos de caráter jurídico ou alegadamente científicos. Quando as parlamentares afirmam que a vida é um dom de Deus (religioso), que o aborto é um homicídio (moral), que a Constituição Federal garante a inviolabilidade da vida (jurídico) ou que a vida começa na concepção (científico), elas procuram consolidar um sentido para a vida e uma base para sua defesa em termos que se contrapõem ao direito ao aborto. Além desses argumentos, o da opinião pública também foi frequente (11 discursos), recorrendo à ideia de uma maioria contrária ao aborto. Vale observar que não aparece, no debate, uma reflexão que nos parece pertinente sobre em que medida a opinião pública poderia ser mobilizada quando se trata de uma questão de direito fundamental.

Por ser pequeno o número de parlamentares mulheres, torna-se difícil indicar padrões ao longo do tempo. O que podemos constatar é que, de modo geral e não apenas entre as 
mulheres, as posições contrárias ao direito ao aborto são cada vez mais ancoradas em argumentos que procuram apresentar-se como independentes de fundamentos religiosos - expressos como questões morais e de base jurídico-científica. Por outro lado, as posições favoráveis são cada vez mais ancoradas em argumentos de saúde pública, em busca de defender ou ampliar o acesso ao aborto nos casos previstos em lei. Mesmo essa defesa se torna cada vez mais pontual, o que é indicativo de uma correlação de forças na qual, dentro da Câmara dos Deputados, o avanço do conservadorismo restringe a amplitude do debate.

\section{Conclusão}

As mulheres parlamentares contribuíram para que a temática do aborto tivesse maior presença no debate na Câmara dos Deputados entre 1991 e 2014. Tiveram uma participação ampliada e diferenciada especialmente se consideramos apenas os discursos favoráveis ao direito ao aborto $-40 \%$ deles, como dito, foram pronunciados por elas, embora não tenham ultrapassado $10 \%$ do total de parlamentares em nenhuma das legislaturas. A posição que as deputadas mais sustentaram em seus discursos foi a da defesa da ampliação do aborto legal, enquanto os deputados se posicionaram principalmente de forma contrária ao aborto. Além disso, entre as 12 deputadas que mais se pronunciaram, apenas três defenderam posições predominantemente contrárias ao direito ao aborto.

Em relação aos partidos das deputadas, apesar de não ser possível afirmar que as parlamentares de partidos de esquerda sejam favoráveis ao aborto, $89,7 \%$ dos discursos favoráveis ao aborto proferidos por mulheres eram de deputadas desses partidos. E entre os discursos contrários, $44,8 \%$ foram feitos por deputadas de partidos de direita.

Além disso, observamos que dos 63 projetos de lei focados na questão do aborto, dez tiveram mulheres como autoras (sete em co-autoria com homens). E destes dez, oito projetos propõem a ampliação do aborto legal no Brasil. É relevante notar que a 
atuação na proposição de projetos e nos discursos não é homogênea, situação exemplificada pela deputada Sandra Starling (PT/MG), que proferiu apenas um discurso no período pesquisado, mas propôs quatro PLs.

Apesar do destaque das deputadas na defesa do direito ao aborto, isso não significa que as parlamentares tenham tido o aborto como prioridade na sua agenda de atuação de modo mais frequente do que tiveram parlamentares homens. Quando se considera o conjunto dos pronunciamentos, quem mais falou em defesa do direito ao aborto nesse período foi um homem, o deputado José Genoíno (PT/SP). Foi ele, também, quem apresentou o maior número de discursos em defesa da descriminalização do aborto.

É preciso, no entanto, considerar a atuação das mulheres e sua agenda em um contexto em que elas são minoritárias. As barreiras diferenciadas para o acesso de mulheres e homens a cargos eletivos vêm sendo analisadas pela literatura há décadas, em diferentes perspectivas (cf. algumas sistematizações desse debate em Araújo, 2005; Biroli, 2016; Krook; Mackay, 2015; Miguel; Biroli, 2010; Phillips, 1991; Sapiro, 1998). Elas são de caráter sociopolítico, envolvem a vida cotidiana, o funcionamento dos partidos e das instituições, as normas correntes, mas também o conjunto de costumes e de regras informais e nem sempre ditas que organizam o ambiente político. Não é possível discutir a atuação substantiva das mulheres - e é disso, ainda que de um prisma restrito à questão do aborto, que trata este artigo - sem levar isso em conta.

Por outro lado, é preciso também considerar que a atuação política existe fora do parlamento e incide na correlação de forças dentro dele. Isso é verdade para as barreiras ao acesso das mulheres à política institucional, como no caso da divisão sexual do trabalho, que se desdobra em menos tempo e menos recursos para as mulheres (Biroli, 2016), mas é também um elemento importante para compreender como atuam as mulheres, mesmo com representação restrita nos cargos eletivos. Os movimentos feministas têm atuado sistematicamente, produzindo pequenos 
avanços e tendo impacto na construção do sentido da vida e do aborto.

É fora do parlamento, também, que se dá a movimentação que sustenta as carreiras políticas dos principais opositores do direito ao aborto, que são homens religiosos. No caso dos parlamentares evangélicos, trata-se de pastores que concorreram a eleições destacando como parte da sua agenda a promoção de valores religiosos, que incluiriam a oposição ao aborto e uma ideia nem sempre claramente explicitada, mas cada vez mais central às disputas, de defesa da família.

Ao mesmo tempo em que parlamentares conservadores apostam na pauta do aborto como forma de alavancarem suas carreiras políticas, parlamentares mulheres favoráveis à ampliação desse direito podem temer constrangimentos e prejuízos às suas carreiras ao optarem por não focarem sua atuação na questão do aborto. Casos como o da eleição presidencial de 2010, quando o aborto ganhou destaque no pleito, podem interferir nessa percepção. Além disso, como discutido no artigo, há uma certa dissonância entre a atuação das deputadas e do movimento feminista que pode ser percebida quando analisamos os argumentos presentes nos discursos $e$ observamos que as deputadas mobilizaram principalmente a questão da saúde pública, deixando de lado o argumento do controle sobre o próprio corpo, e mobilizando pouco a liberdade individual. $\mathrm{Ou}$ quando, em 2005, o movimento conseguiu que fosse criada a comissão tripartite, mas o número de pronunciamentos favoráveis ao direito ao aborto foi irrisório.

Neste artigo, procuramos contribuir para a reflexão sobre as conexões entre a atuação política das mulheres. Embora ela seja pequena e localizada, devido à sub-representação no Congresso, é importante compreender quem são as parlamentares e como atuam. Nosso estudo permitiu ampliar a compreensão dessa atuação na temática do aborto. 


\section{Referências bibliográficas}

AlmeIDA, Tânia Mara; BANDEIRA, Lourdes. O aborto e o uso do corpo feminino na política: a campanha presidencial em 2010 e seus desdobramentos atuais. cadernos pagu (41), Campinas-SP, Núcleo de Estudos de Gênero-Pagu/Unicamp, 2013, pp.371-403.

Alvarez, Sonia E. Engendering democracy in Brazil: women 's movements in transition politics. Princeton, Princeton University Press, 1990.

ARAÚJO, Clara. Partidos políticos e gênero: mediações nas rotas de ingresso das mulheres na representação política. Revista de Sociologia e Política, n 24 , Curitiba-PR, UFPR, 2005, pp.193-215.

BIROLI, Flávia. Autonomia e justiça no debate sobre aborto: implicações teóricas e políticas. Revista Brasileira de Ciência Política $\mathrm{n}^{0}$ 15, Brasília, Instituto de Ciência Política da Universidade de Brasília, 2014, pp.37-68.

BIROLI, Flávia Divisão sexual do trabalho e democracia. Dados, vol. 59, $n^{\circ}$ 3, Rio de Janeiro-RJ, IESP-UERJ, 2016, pp.257-90.

BIROLI, Flávia; Miguel, Luis Felipe (orgs.). Aborto e democracia. São Paulo, Editora Alameda, 2016.

CORRÊA, Sônia; ÁVILA, Maria Betânia. Direitos sexuais e reprodutivos Pauta global e percursos brasileiros. In: BERQUÓ, Elza (org.). Sexo \& Vida: panorama da saúde reprodutiva no Brasil. Campinas-SP, Editora da Unicamp, 2003, pp.17-78.

DIAP. Série de estudos políticos. Radiografia do novo Congresso Nacional. Legislatura (2003-2007). 2.ed., ano 2, Brasília, DIAP [http://www.diap.org.br/index.php?option $=$ com jdownloads\&Itemid $=243 \&$ view $=$ finish $\&$ cid $=266 \&$ catid $=41-$ acesso em 2 dez. 2015].

DIAP. Série de estudos políticos. Radiografia do novo Congresso Nacional. Legislatura (2007-2011). 4.ed., ano 4, Brasília, DIAP [http://www.diap.org.br/index.php?option $=$ com_jdownloads\&Itemid $=513 \&$ view $=$ finish $\&$ cid $=267 \&$ catid $=41-$ acesso em $2 \mathrm{dez} .2015]$.

DIAP. Série de estudos políticos. Radiografia do novo Congresso Nacional. Legislatura (2011-2015). 5.ed., ano 5, Brasília, DIAP [http://www.diap.org.br/index.php?option $=$ com_jdownloads\&Itemid 
$=513 \&$ view $=$ finish $\&$ cid $=355 \&$ catid $=41-$ acesso em 2 dez. 2015].

DiNIZ, Débora; MedeIROS, Marcelo. Aborto no Brasil: uma pesquisa domiciliar com técnica de urna. Ciência \& Saúde Coletiva n ${ }^{\circ} 15$, Rio de Janeiro, ABRASCO, 2010, pp.959-966.

DINIZ, Débora et al. A verdade do estupro nos serviços de aborto legal no Brasil. Revista de Bioética vol. 2, n 22 , Brasília, Conselho Federal de Medicina, 2014, pp.291-8.

KROOK, Mona Lena; MACKAY, Fiona. Gender, politics, and institutions: towards a feminist institutionalism. Londres, Palgrave Macmillan, 2015.

MACHADO, Lia Zanotta. Feminismo em movimento. Brasília, Editora Francis, 2014.

MACHADO, Maria das Dores Campos. Discursos pentecostais em torno do aborto e da homossexualidade na sociedade brasileira. Revista Cultura e Religião vol. 7, n 2, Chile, Universidad Arturo Prat, 2013, pp.48-68.

MANTOVANI, Denise. Quem agenda a mídia? Um estudo de agenda setting a partir da tematização do aborto nas eleições de 2010. Tese (Doutorado em Ciência Política), Universidade de Brasília, Brasília, 2014.

MARIANO, Rayani. O debate parlamentar sobre aborto no Brasil: atores, posições e argumentos. Dissertação (Mestrado em Ciência Política), Universidade de Brasília, Brasília, 2015.

Miguel, Luis Felipe. Aborto e democracia. Revista Estudos Feministas vol. 3, no 20, Florianópolis-SC, UFSC, 2012, pp.657-672.

Miguel, Luis Felipe; BiRoli, Flávia. Práticas de gênero e carreiras políticas: vertentes explicativas. Revista Estudos Feministas, vol. 18, n 3, Florianópolis-SC, UFSC, 2010, pp.653-79.

Miguel, Luis Felipe; BIROLI, Flávia; MARIANO, Rayani. O debate sobre aborto no Brasil: posições e argumentos na Câmara dos Deputados. In: BIROLI, Flávia; MigUEL, Luis Felipe (orgs.). Aborto e democracia. São Paulo, Editora Alameda, 2016, pp.127-154.

MINISTÉRIO DA SAÚDE. Secretaria de Atenção à Saúde, Área Técnica de Saúde da Mulher. Magnitude do aborto no Brasil: aspectos 
epidemiológicos e sócio-culturais. Ministério da Saúde, Brasília, 2008.

MINISTÉRIO DA SAÚDE. Indicadores e Dados Básicos (IDB)., Rede Interagencial de Informações para a Saúde (RIPSA), Ministério da Saúde, Brasília, 2012.

PHILLIPS, Anne. Engendering democracy. Pennsylvania, The Pennsylvavia State University Press, 1991.

PINTO, Céli R. J. Uma história do feminismo no Brasil. São Paulo, Perseu Abramo, 2003.

SAPIRO, Virginia. Feminist studies and Political Science. In: PHILLIPS, Anne (ed.). Feminism and Politics. Oxford University Press, 1998, pp.67-92.

\section{Discursos citados}

Angela Guadagnin (PT/SP), Diário da Câmara dos Deputados. Ano LX, N. 215, p. 59690-596903, 8 dez. 2005.

Cida Diogo (PT/RJ), Diário da Câmara dos Deputados. Ano LXIII, N. 65, p. 19550-19551, 8 maio 2008.

Elaine Costa (PTB/RJ), Diário da Câmara dos Deputados. Ano LX, N. 211, p. 58857-58858, 2 dez. 2005.

Jandira Feghali (PCdoB/RJ), Diário da Câmara dos Deputados. Ano LIX, N. 194, p. 49556-49560, 18 nov. 2004.

Jô Moraes (PCdoB/MG), Diário da Câmara dos Deputados. Ano LXIII, N. 66, p. 19955-6, 9 maio 2008.

Maria Elvira (PMDB/MG), Diário da Câmara dos Deputados. Ano L, N. 49, p. 9195-9196, 14 dez. 1995.

Marta Suplicy (PT/SP). Diário da Câmara dos Deputados. Ano LII, n. 215, p. 38403, 26 nov. 1997.

Perpétua Almeida (PCdoB/AC), Diário da Câmara dos Deputados. Ano LXIII, N. 212, p. 58941- 58946, 12 dez. 2008.

Sandra Starling (PT/MG), Diário da Câmara dos Deputados. Ano LII, N. 215, p. 38382, 26 nov. 1997.

Socorro Gomes (PCdoB/PA), Diário da Câmara dos Deputados. Ano XLVI, N. 127, p. 18519-18520, 27 set. 1991. 
Solange Almeida (PMDB/RJ), Diário da Câmara dos Deputados. Ano LXIII, N. 14, p. 3085-3086, 20 fev. 2008.

Zelinda Novaes (PFL/DEM/BA), Diário da Câmara dos Deputados. Ano LX, N. 216, p. 60168-60169, 9 dez. 2005. 